\title{
Prospects of a Christian ethics of responsibility (Part 2): an assessment of three German versions
}

\author{
D E de Villiers \\ (University of Pretoria)
}

\section{ABSTRACT}

Prospects of a Christian ethics of responsibility (Part 2): an assessment of three German versions

In the article three versions of a Christian ethics of responsibility, developed by three German theologians, Wolfgang Huber, Johannes Fischer and Ulrich Körtner, in response to the philosopher Hans Jonas's introduction of the ethics of responsibility as a completely new and much needed ethical approach in the technological age, are analysed and assessed. The purpose is to assess the prospects of a Christian ethics of responsibility. An analysis shows the disparate nature of the three versions, but also reveals a number of ways in which responsibility can and should fundamentally qualify contemporary Christian ethics. The conclusion is therefore that the prospects of a Christian ethics are much more promising than a superficial comparison of the three disparate versions of such an ethics would suggest.

\section{INTRODUCTION}

The theme of a Christian ethics of responsibility is not new. Renowned theologians like Dietrich Bonhoeffer and $\mathrm{H}$ Richard Niebuhr wrote extensively on Christian responsibility in the middle decades of the twentieth century and presented their own versions of a Christian ethics of responsibility. Their views have exercised enormous influence and have also received ample attention in theological dissertations and publications ${ }^{1}$. Since the eighties, in the aftermath of the publication of the philosopher Hans Jonas's book Das Prinzip Verantwortung: Versuch einer Ethik für die

1 Dietrich Bonhoeffer developed his views on Christian responsibility in the late nineteen thirties and early nineteen forties. His views were developed in mainly his Ethics and Letters and papers from prison, which were both published only after his death and the Second World War. H Richard Niebuhr developed his views on Christian Ethics of Responsibility in his book The responsible self (1963). Their views are discussed in, amongst others, A R Jonsen, Responsibility in modern religious ethics (1968) and W Schweiker, Responsibility and Christian Ethics (1995). 
technologische Zivilisation (in German 1979 and in American 1984) a new spate of German and American theologians have developed their own versions of a Christian ethics of responsibility in dialogue with Jonas ${ }^{2}$. Their views on such an ethics have received little systematic treatment up till now.

In an earlier article I assessed Jonas's conception of an ethics of responsibility, as well as William Schweiker's attempt to develop a Christian version in close proximity to Jonas's conception (De Villiers 2006:468-487). My conclusion was that the attempt to develop a Christian ethics of responsibility that closely reflects Jonas's conception does not hold much promise. Jonas's attempt to elevate responsibility to the substantive normative principle of the new ethics he proposes, is problematic. Although he argues convincingly that the prospective responsibility for the survival of humankind should receive far more emphasis in contemporary ethics, his plea for the complete transformation of ethics into future ethics is one-sided. Equally inconclusive is his assumption that only an ethics based on a universally recognised foundation can warrant prospective responsibility for the future survival of humankind.

This article critically discusses the conceptions of a Christian ethics of responsibility of three theologians who have published mostly in German: Wolfgang Huber from Germany, Johannes Fischer from Switzerland and Ulrich Körtner from Austria ${ }^{3}$. Although their versions of such an ethics are quite disparate, they have in common that they maintain a greater critical distance to Jonas's view than Schweiker. They do not make an imperative of responsibility the centrepiece of their own views, do not conceive an ethics of responsibility as an exclusively future ethics and do not try to find a universally recognised foundation for it.

The disparity of their views, however, raises a question regarding the common and recognisable features of a Christian

2 See the list of Consulted literature for the title of the American edition of Jonas's book.

3 Other German theologians have also developed versions of a Christian ethics of responsibility, amongst others: Hartmut Kress, Wolfgang Erich Müller and Josef Römelt (see the Bibliogrphy for some of their publications). For discussion in this article I have selected the views of three influential Protestant German theologians, who have written extensively on the ethics of responsibility. 
ethics of responsibility. This raises another serious question: how viable is a Christian ethics of responsibility as a distinctive approach if there is seemingly no agreement amongst its proponents on its defining features?

In this article I would like to demonstrate that the prospects of a Christian ethics of responsibility are not as bleak as it may seem at first sight. First of all, it can be demonstrated that some conceptions are more convincing than others. If some of the views of the three theologians on the defining features are retained, while others are rejected or adapted, the problem regarding disparity do not seem to be insurmountable. Secondly, I am of the opinion that their views point convincingly to the undeniable centrality of responsibility in contemporary ethics. They help us to identify more than one way in which the concept of responsibility indelibly stamps contemporary ethics, including Christian ethics. In my opinion this centrality of responsibility may warrant the conclusion that Christian ethics in our day and time can only be conceived as an ethics of responsibility.

The article starts out with a brief description of the three named theologians' conceptions of a Christian ethics of responsibility and then moves on to a comparison and evaluation of their conceptions. In a last section some concluding remarks are made with regard to the prospects of Christian ethics of responsibility as a distinctly contemporary approach.

\section{WOLFGANG HUBER, JOHANNES FISCHER AND ULRICH KÖRTNER: ALTERNATIVE PROPOSALS FOR A CHRISTIAN ETHICS OF RESPONSIBILITY}

Wolfgang Huber was the first of the three contemporary representatives of a Christian ethics of responsibility who took part in the public debate on this topic shortly after the publication of Jonas' book in Germany in 1979. Since the early nineteen eighties he read papers and wrote articles in which he propagated the development of Christian social ethics as an ethics of responsibility and discussed particular contemporary problems related to responsibility ${ }^{4}$. As can be expected, Huber pays much attention to

4 Huber developed his own views on a Christian or theological ethics of responsibility especially in a paper: Sozialethik als Verantwortungsethik, read in 1982 (published in 1990 in a collection of papers and articles by Huber: Konflikt und Konsens: Studien zur Ethik der Verantwortung, 135-157) and a 
Hans Jonas and his future ethics. From the start, however, he has orientated himself also to Max Weber's original conceptualisation of an ethics of responsibility. One of the results is that he does not focus only on technological development and its ethical implications, but also pays attention to other aspects of modernisation and related ethical implications.

In an attempt to define contemporary Christian ethics of responsibility Wolfgang Huber, first of all, points out that it deals with three new challenges with regard to responsibility (Huber 1993:574-578):

(i) Collective crimes of obedience.

(ii) The globalisation of modern technology.

(iii) The ambivalence of the project of modernity (the increase of autonomy on the one hand and the breakdown of lived traditions on the other hand).

He further identifies four basic characteristics, or structural dimensions of such an ethics:

(i) Foundation in a relational anthropology (Huber 1993:580584). In Huber's opinion all theological ethics of responsibility rely on a relational rather than a substantialist anthropology. The two most prominent representatives of a Christian ethics of responsibility in the twentieth century, Dietrich Bonhoeffer and $\mathrm{H}$ Richard Niebuhr, have in common that they understand the human person as responder. They already recognised two different structures of relationship in responsibility: responsibility to and responsibility for. Huber is of the opinion that "responsibility for" is not simply care (Fürsorge) - as Bonhoeffer still thought - but includes prospective care (Vorsorge). From a Christian perspective humans are in the last instance "responsible to" God.

paper: Toward an ethics of responsibility, read in 1992 (published in 1993 in: The Journal of Religion 73(4), 573-591). However, see also the paper read in honour of H E Tödt after his death in 1992: Strukturen verantwortlichen Lebens: Die Bedeutung Heinz Eduard Tödts für die theologische Ethik, and the articles: Selbstbegrenzung aus Freiheit: Über das ethische Grundproblem des technischen Zeitalters, Evangelische Theologie 52 (1992), 128-146 and Gewalt gegen Mensch und Natur - Die Notwendigkeit eines planetarischen Ethos, in: J Rehm (ed.), Verantwortlich leben in der Weltgemeinschaft: Zur Auseinandersetzung um das "Projekt Weltethos", 1994, 30-46. 
(ii) Correspondence to reality (Huber 1993:584-586). It is conspicuous that not only in Max Weber's original conceptualisation of an ethics of responsibility, but also in Bonhoeffer's and Niebuhr's theological versions of such an ethics, the notion of correspondence to the real world is central. In a Christian ethics of responsibility the relationship between the reality of the world and the reality of God is pivotal. It is a relationship that should be understood from the perspective of an incarnational theology. From a Christian perspective correspondence to reality does not mean the conformity to the functional imperatives of the partial systems of society (Eigengesetzlichkeit). It means participation in the ongoing struggle to bring the criteria of humanity to bear under the given and ambiguous conditions of action emerging in the historical character of society. Also, in Huber's opinion, it poses the challenge to a Christian ethics of responsibility to contribute constructively to the search for a "planetary ethos" that can provide minimal conditions for the survival of humankind and the preservation of nature (Huber 1994:37).

(iii) Teleological character (Huber 1993:586-588). In Huber's opinion an ethics of responsibility has to be understood basically as a teleological ethics. In a Christian ethics the distinction between eschatology and teleology should, however, be taken seriously. It means, among others, that the relative and finite nature of tele that can be accomplished by human action has to be acknowledged in the light of the eschaton that can only be brought about by God. According to Huber it implies the duty of self-limitation with respect to the life conditions and the freedom of future generations (Huber 1992a:128-146).

(iv) The reflexive use of principles (Huber 1993:588-589). Huber believes that the distinctive character of an ethics of responsibility can be clarified by referring to Max Weber's characterisation of such an ethics as one that makes use of principles not in a simple way, but reflexively. Especially since the Enlightenment, people have found themselves in a social world characterised by a plurality of religious and ethical orientations. To respond to such a situation in an appropriate way one has to relate one's principles in a reflexive manner to the principles of others. One has to take the freedom of conscience of others as seriously as one's own. Included in such deliberations is the weighing of consequences that would follow the application of principles. The comparison of principles and the 
assessment of consequences therefore become central to every ethical orientation. In Huber's opinion a Christian ethics of responsibility has to follow suit, because the reflexive use of principles is nothing but the application of the Golden Rule on the level of principles.

Of the three theologians discussed in this article Johannes Fischer's endorsement of an ethics of responsibility is the most qualified $^{5}$. If attempts to identify ethics of responsibility with ethics as a whole and to reduce it to a future ethics with the survival of humankind as its sole aim, are relinquished, a legitimate, but limited role can, in his opinion, be assigned to such an ethics. The reason is that ethics - and that includes Christian ethics - relates to three different levels or manifestations of the good that humans strive at. As humans we have to get answers to the following questions concerning the good: What is the good that we have to strive for in this life? What is the good we owe others that is our responsibility? What is the trans-subjective good that determines our lives, the "spirit" from which we live and in which we communicate with each other (Fischer 1994:9-10)? The first question is the leading question of the type of ethics that was given its classical form by Aristotle and up till now has played a major role in the history of Western thought. Fischer depicts this type of ethics as ethics of doing (German: "TunEthik"). The second question is the leading question of the second basic type of ethics, which has its roots in the Judeo-Christian tradition, with its central tenet that humans are in everything they do responsible to God. Fischer calls this type ethics of action (German: "Handlungs-Ethik") or ethics of responsibility. The third question is the leading question of the third basic type of ethics, which also has its roots in the Judeo-Christian tradition. A very influential paradigm

$5 \quad$ Fischer first wrote an article: Christliche Ethik als Verantwortsethik?, Evangelische Theologie 52(2), 114-128. He developed his view on an ethics of responsibility as part of a more comprehensive framework of Christian ethics in his book: Leben aus dem Geist: Zur Grundlegung christlicher Ethik (1994). In his book Handlungsfelder angewandter Ethik: Eine theologische Orientierung (1998) he applied his theoretical view on Christian ethics to particular ethical issues relating to human sexuality, bio-ethics, ecology and politics, but also elaborated certain aspects of his theoretical view on Christian ethics. In his most recent book: Theologische Ethik: Grundwissen und Orientierung (2002) Fischer discusses responsibility as central concept in contemporary ethics, but does not use the term "ethics of responsibility" anymore. 
of this type of ethics, which Fischer calls the ethics of life determined by the (S)spirit, is found in the New Testament (cf. Gl. 5,25). This last type of ethics is in Fischer's opinion the most fundamental in that it incorporates and integrates the other two types (Fischer 1994:10-13).

As a result of the fact that the ethics of action is closely associated with "holding responsible" and "giving account of" Fischer is of the opinion that it can also be depicted as ethics of responsibility. By doing that he distances himself from the tendency to regard the concept ethics of responsibility as only of recent origin and to regard the turn to the ethics of responsibility as typical of the ethical situation we find ourselves in today. Contrary to Georg Picht's assertion that the German word for "responsibility" ("Verantwortung") was first used and given meaning in the Middle Ages in the legal context and only later transferred to the religious context to refer to accountability before God as Judge, he asserts that the concept of responsibility already received its definitive content in the Judeo-Christian tradition, although the word "responsibility" was coined much later. Central to this tradition was the belief that human beings are responsible to God in everything they do. The ethics of the Judeo-Christian tradition is therefore, in his opinion, in an eminent sense, ethics of responsibility (Fischer 1994:110-112).

In Fischer's opinion this does not imply that Christian ethics can one-sidedly be defined in terms of the ethics of responsibility. One should take into account that the motif of love also played a central role in the Judeo-Christian tradition. This motif points to an even more fundamental dimension of Christian ethics that stands in a relationship of tension to the ethics of responsibility and qualifies and relativises it (Fischer 1994:112-114). In the course of the history of the church the creative tension between the motifs of responsibility and of love was unfortunately ignored, with the result that the ethics of responsibility became the dominant ethics. The commands of God the Judge, which had to be obeyed unconditionally by humans, became the point of departure in Christian ethics. In this way Christian ethics was transformed into a heteronomous ethics of law or norms. In reaction the Divine Judge was internalised during the Enlightenment and the conscience became the internal court before which final account had to be given. With that the transition within the paradigm of the ethics of responsibility from heteronomy to autonomy, and from an ethics of 
law to an ethics of conviction took place. With the arrival of the ethics of conviction the ethics of responsibility also proceeded into its profane phase (Fischer 1994:115-116).

According to Fischer we have realised in recent times that the Enlightenment attempt to ground objective moral duties that are universally valid in human subjectivity, is in vain. This has led to the realisation that we cannot appeal to objective commands, duties or norms that are given to us by one or the other instance. The central ethical issue is not anymore: "What are we responsible for?" but rather: "What do we want to, or should we, make each other responsible for?” In other words, it is not our task anymore to discover moral responsibility, but to create or constitute it mutually. In Fischer's opinion that is what is new with regard to the present ethical situation. Heteronomy and autonomy have been relieved by the principle of koinonomy (Fischer 1994:117-118). Christian ethics has to accept this fact. Instead of trying in vain like Jonas to ground our moral responsibility objectively in human nature or the nature of the world it should rather endorse the search for that which we should make each other responsible for and contribute constructively to the societal process of restoring moral responsibility (Fischer 1994:120-121).

Like Huber and Fischer Körtner is convinced that Christian Ethics should be construed as ethics of responsibility ${ }^{6}$. Responsibility should be the leading concept of a Christian ethics attuned to the time in which we are living. In his opinion that does not mean that Christian ethics can be based solely on the concept of responsibility. Christian social ethics, for example, is primarily based on a theory of goods or values, in which the goods or values that we have to realise or protect in society are spelt out. To a theory of goods can be added a theory of duties and a theory of virtues that also form intrinsic parts of Christian ethics. However, these three

6 Körtner's views on a Christian ethics of responsibility are developed in the following publications: Dem Risiko trotzen: Grundzüge einer zeitgemässen Verantwortungsethik, Evangelische Kommentare (1996), 581-586; Prinzip Verantwortung? Begründungsprobleme heutiger Verantwortungsethik, Glaube und Lernen (1997a), 136-147; Solange die Erde steht: Schöpfungsglaube in der Risikogesellschaft (1997b); Evangelische Sozialethik: Grundlagen und Themenfelder (1999); Freiheit und Verantwortung: Studien zur Grundlegung theologischer Ethik (2001). 
aspects or dimensions are integrated by means of the concept of responsibility, so that Christian ethics can rightly be described as ethics of responsibility (Körtner 1996:581; 1999:11).

To understand fully how the concept of responsibility puts its stamp on our contemporary understanding of morality, one has, in Körtner's opinion, to take into account that the verb "respond" (and its derivatives) has its historical roots in die juridical sphere and originally meant: "to defend oneself in court" (cf. the Latin: respondere, probare). Since Kant an ethics of conviction - with duty and autonomy as its central concepts - understood the moral agent as analogous to the lawmaker. In contrast an ethics of responsibility characterises the fundamental moral situation as a forensic one. As forensic concept responsibility is closely related to the concept of imputation (Latin: imputatio). As such it presupposes an accountable agent, on the one hand, and - analogous to a judge - an instance holding the agent accountable for his actions and their consequences, on the other hand. The central questions in the fundamental moral situation depicted as forensic are: who is the responsible agent, who (or what) is the instance holding the agent responsible, and what is the sphere in which the agent is held responsible? (Körtner 1996:581; 1997a:137-138; 1999:66-67).

Körtner is convinced that a theological concept of responsibility should not be developed in conjunction with a preceding philosophical concept of responsibility. Theologically the concept of responsibility does not only have its own foundation, but also its own content. From a theological perspective the identification of the instance holding us responsible with the individual conscience or future generations seems questionable. Theological ethics understands human beings as God's creatures. God the Creator is the One who has the right to hold us responsible for the way in which we deal with his creation.

In Körtner's opinion the idea of global responsibility for the creation only gains theological profile if the unique relationship between the concepts of responsibility and justification - as understood from a Christian perspective - is taken into account. Theologically the duty of the agent to give account of herself is preceded by the justification of the sinner by a merciful God. The philosophical argument that personal recognition is the ground of morality has its theological point in that the recognition of the person by God is the basis for interpersonal recognition. On account of 
God's recognition of the person her dignity and freedom has to be recognized unconditionally. When the right to life of the individual is theologically based in the justification of the sinner, it cannot interpersonally be understood only in terms of moral conditions. The reverse is rather true: morality has to be measured in terms of God's recognition (Körtner 1997a:146).

A Christian ethics of responsibility based on the doctrine of justification is faced with the problem that it is based on premises that claim to be universally valid, but cannot be universalised in abstract form. However, if the historical relativity of all ethical insights is taken into account, one may ask whether all efforts to ground a universally recognised ethics of responsibility are not illusionary. A Christian ethics of responsibility based on the doctrine of justification recognises this fact, without giving up its promotion of global responsibility. The responsibility for the world that is part of Christian faith is not observed by claiming that it is based on premises that are accepted by everyone, but by the solidaric participation in seeking for an answer (Körtner 1997a:147; 1999:95, 104-105).

\section{COMPARISON AND EVALUATION OF THE THREE VERSIONS}

When the views of Huber, Fischer and Körtner on a Christian ethics of responsibility are compared one is struck not so much by the similarities, than by the differences between their views. All three of them endorse a Christian ethics of responsibility and deny that such an ethics has responsibility as substantive normative principle, should be conceived as an exclusively future ethics, and is in need of a universally recognised foundation. Apart from that there is seemingly very little that their views have in common. Most conspicuous is the fact that they have completely different views on the definitive features of a Christian ethics of responsibility. For Fischer it is one basic type or category of normative ethics amongst others, which strives to spell out what the good is we owe to others. In his theological ethics the term "ethics of responsibility" is nothing more than a depiction for what is usually called the "ethics of duty" or "duty ethics" that makes out only one part of a more comprehensive Christian ethics. As the ethics of responsibility has from the start made out an indispensable part of Christian ethics, the depiction "ethics of responsibility" has, in his opinion, no specifically contemporary connotations. For Huber the term 
"Christian ethics of responsibility" depicts all Christian normative ethical theories that engage the new challenges with regard to responsibility in our time and are characterised by certain features. He clearly sees "Christian ethics of responsibility" as an inclusive term that refers to the whole of Christian ethics and definitely has contemporary connotations. For Körtner Christian ethics of responsibility is a distinctly contemporary ethics in which the fundamental moral situation is not understood in terms of duty anymore, but in terms of responsibility as a forensic concept. Responsibility is the integrating concept of Christian ethics as a whole, which includes theories of duty, virtue and value.

By reducing Christian ethics of responsibility to only one dimension of Christian ethics as a whole and by asserting that it has since the Enlightenment proceeded into a secular phase, Fischer intentionally distances himself from the view, shared by Huber and Körtner, that such an ethics can be seen as an alternative, specifically contemporary approach to Christian ethics. His view is based on two main arguments: first, conceiving the whole of Christian ethics as ethics of responsibility would result in a functionalist reduction of Christian ethics, and, second, an analysis of Christian ethics shows that it consists of three dimensions, one of which has been, from the start, the ethics of responsibility.

Fischer seemingly assumes that conceiving the whole of Christian ethics as ethics of responsibility is the same as conceiving it as an exclusively future ethics, solely concerned with the future survival of humankind. In the light of Hans Jonas' view of the ethics of responsibility such an assumption is understandable. It is, however, an assumption that can be disputed. Huber demonstrates that it is quite possible to conceive of Christian ethics as ethics of responsibility without reducing it to future ethics. Such an ethics can and should, in his opinion, also be concerned with other issues regarding moral responsibility for the past and the present. This does not mean that there is anything wrong in insisting that a Christian ethics of responsibility should be strongly concerned with the future survival of life on earth. Christian ethics would be irresponsible if it does not engage seriously with the increasing risk technological advance poses for all life on planet earth. As long as it is not conceived solely as future ethics, its endorsement of such a comprehensive responsibility to eliminate risks does not necessarily imply the functionalist reduction of Christian ethics. One should also 
not play off the Christian belief that the future lies in God's hand against human responsibility to secure the future survival of life on earth as far as possible. The meaning of this belief lies in the message that Christians need not despair about the future, but should approach it with a positive attitude, because they can put their trust in God's providence. This belief does not contravene or limit human responsibility in any way, but rather enables believers to exercise optimally the comprehensive moral responsibility they have. Part of this comprehensive moral responsibility that Christians have is the collective responsibility - together with other people - to do prospectively everything within their means to avoid risks that threaten the survival and quality of life in future.

The threat of a functionalist reduction of the attempt to secure the future survival of life on earth lies not so much in conceiving Christian ethics as responsibility ethics, but rather in eliminating the contribution of ethics from the attempt to secure this survival. It is the belief that the risks involved with modern technology can be overcome by solely technological means that poses the real threat of a functionalist reduction. The temptation to opt for the survival of only human beings at the cost of other life forms, or for the survival of only certain segments of the human population at the cost of other segments, would be very difficult to withstand on such a basis. Such temptations can only be withstood by involving ethics - including Christian ethics - in finding morally acceptable ways in which the future survival of life on earth can be secured. A Christian ethics of responsibility can play an important role in this regard. In doing so it would be fulfilling a task that has a distinctly contemporary flavor.

Fischer's analysis of the different dimensions of Christian ethics is highly original. In his own way he demonstrates convincingly that Christian ethics is rooted in a fundamental dimension of life in which no clear distinctions between morality and religion can be made. His attempt to restrict the ethics of responsibility to what is usually called duty ethics and to deny the distinctly contemporary nature of such an ethics is less convincing however. His argument seems to be that "ethics of responsibility" is an apt depiction for duty ethics, because moral responsibility is only at stake in it and not in the other dimensions of Christian ethics. One may, however, ask: can it really be maintained that responsibility over against fellow human beings and God is not at stake in the other two aspects of Christian ethics: ethics of action and ethics of life 
determined by the Spirit? Is it really true that we are not responsible to them with regard to the good we strive for in this life and the realisation of the trans-subjective good that determines our lives? One only needs to point to Aristotle's ethics, which Fischer regards as the classical model of an ethics of action, to illustrate that it is not possible to distinguish strictly between the good we strive for in this life and the good we owe others. For Aristotle the nurturing of virtues is not a strictly private matter that concerns the individual only. The nurturing of virtues in children, for example, is a responsibility of the family and society, while the individual is responsible to other individuals and society for the virtues she displays or does not display. It is true that in Paul's letters the transsubjective good that determines our life is God's gift of redemption as a result of our reconciliation with Him through Christ. It is also true that the main motive for embodying this gift in our personal lives is spontaneous love for God and fellow human beings. However, it does not mean that we are not responsible to God and to fellow human beings for this embodiment in our attitudes and actions. For example, if we do not embody God's forgiveness in our own forgiving attitudes and actions towards our fellow Christians we stand guilty before them and before God. The conclusion seems inevitable that there is no reason to restrict responsibility to only one aspect of Christian ethics. Responsibility seems to be at stake in all dimensions of Christian ethics. The implication for the use of the term "ethics of responsibility" seems to be that it is either applicable to the whole field of Christian ethics, or not applicable to any aspect at all.

Another problem is that Fischer, in denying that ethics of responsibility is distinctly contemporary and in equating it with duty ethics, may be ignoring that more is at stake in the relatively recent introduction of the terms "responsibility" and "ethics of responsibility" in the fields of philosophy and ethics. He is of course correct that the idea of accountability or imputation inherent to the concept of responsibility is not new. In both the Old and New Testament accountability to God and - one may add - to fellow human beings is already present. However, one can ask whether Fischer is correct in arguing that this idea had its origin solely in Judeo-Christian religion. Accountability seems to be rather an inherent part of what it means to be human, although there may have been changes in its understanding in the history of humankind, for 
example, from collective to individual responsibility. However, fact of the matter is that other terms were used to refer to this accountability in philosophy and theology in the English speaking world up till the nineteenth century, for example the word "imputation". The historian Richard McKeon has pointed out that the term "responsibility" has only come into regular philosophical usage since the middle of the nineteenth century (McKeon 1957:67). The large-scale substitution of the term "duty" in our time by the term "responsibility" does not seem to be coincidental. Philosophers have often pointed out that the terms "duty" and "responsibility" do not have the same meaning. Duties are explicit guidelines for action in which very specific instructions on what should be done, are given. Prospective responsibility only lays down the general obligation to avoid certain harm or realise certain desirable conditions. Decisions on the specific course of action to be taken are left to the responsible persons or person. To quote Carl Mitcham: "The responsible citizen or scientist or engineer is not the same as the citizen or scientist or engineer who does his or her duty... To measure a person by the standards of responsibility is not the same as to measure someone by the standards of deontology... The person who performs his or her duty is focused, single-minded, sticks to the prescribed part... The responsible individual by contrast, takes all things into account. This almost always means being conscious of a wider range of factors than the person of duty..." (Mitcham 1987:27). In other words: the substitution of the term "duty" by the term "responsibility" may be an indication of a fundamental shift in our contemporary understanding of moral obligation. The term "ethics of responsibility" could, in turn, express recognition of the fact that ethics can today only be regarded as adequate if it reflects this fundamental shift.

Despite his denial that the ethics of responsibility is distinctly contemporary, Fischer does recognise that this ethics has changed fundamentally in its transition from an ethics of conviction to a koinonomy ethics. In his opinion the realisation that we cannot ground objective moral duties that are universally valid in human subjectivity, as Enlightenment philosophers believed, implies the recognition of the new meta-responsibility to create or constitute moral responsibility mutually. As we cannot discover universal moral responsibility it becomes our task to find consensus through dialogue on what we should make each other morally responsible 
for. As a result of the fact that science and technology develop so rapidly that existing moral covenants can often not provide adequate moral guidance, this meta-responsibility involves also the continuing formulation of and agreement on completely new norms (Fischer 1994:265-266). If Fischer is correct in asserting that this metaresponsibility has become an indispensable part of ethics in our day, he has identified a specific and new way in which contemporary ethics is fundamentally qualified by responsibility and - contrary to what he believes himself - has also provided a reason for depicting contemporary ethics - including Christian ethics - as ethics of responsibility.

A close analysis of Huber's and Körtners views reveals some more convincing reasons for conceiving Christian ethics as ethics of responsibility today. Huber starts off his discussion of the distinctive features of a Christian ethics of responsibility by pointing out three new challenges with regard to responsibility to which such an ethics should attend. He seems to imply that attention to these new challenges is part of what should distinguish a Christian ethics of responsibility. As a result of the urgency of these new challenges one can take for granted that Huber is convinced that Christian ethics in our time should seriously grapple with them. But it would go too far to claim that he is of the opinion that the discussion of these contemporary responsibility challenges provides an adequate condition for calling Christian ethics "ethics of responsibility". A discussion of these challenges provides at the most a necessary condition for doing so. On its own it would not justify the depiction of an ethics as "ethics of responsibility".

For Huber the defining features of a Christian ethics of responsibility are found rather in four characteristics shared by versions of such an ethics. The problem is that such a "descriptive" definition of a Christian ethics of responsibility does not provide an answer to the normative question: should Christian ethics as a whole be conceived as ethics of responsibility with a distinctly contemporary nature? It simply lists the common features of those versions of Christian ethics that have up till now claimed the depiction "ethics of responsibility". A further problem is that three of the structural elements that Huber identifies as common to existing versions of Christian ethics of responsibility do not give any indication of why specifically the term "responsibility" is used to distinguish them from other types of Christian ethics. Huber's first 
three structural elements: foundation in a relational anthropology, correspondence to reality and teleological character, do not provide any clarity in this regard. They are features exhibited by many versions of Christian ethics that do not make use of the depiction "ethics of responsibility". Therefore it would make no sense to claim that versions of Christian ethics that exhibit these features qualify as ethics of responsibility. One can argue of course - as Huber probably would - that at least a Christian ethics of responsibility has to exhibit these three structural elements. However, that is not the same as to argue that the presence of these elements - taken separately or together - provides an adequate condition for calling such an ethics an "ethics of responsibility". The presence of these structural elements may be at the most a necessary condition for calling Christian ethics "ethics of responsibility".

It is only when we come to the fourth structural element of a Christian ethics of responsibility that Huber identifies that some clear indication is given of why the term "responsibility" is used in the depiction and why contemporary ethics should be conceived of in terms of responsibility. Huber lays special emphasis on this fourth structural element: the reflexive use of principles as the distinctive feature of an ethics of responsibility. Both the ethics of norms and the ethics of conviction are characterised by a simple use of norms and principles in that they are applied to the concrete situation without taking into account the impact of the resultant action on other people and nature. But the ethics of responsibility involves the responsibility to consider the possible consequences of alternative actions on the freedom of conscience of people with different religious and moral beliefs and on the natural environment, before deciding on what to do. As a result of the increasing moral plurality in contemporary societies the reflexive use of principles have become a fundamental responsibility in contemporary ethics. If Huber is right in asserting that the responsibility to make reflexive use of principles is a condition for adequate ethics in our time, he has identified yet another way in which responsibility should mark contemporary ethics fundamentally, as well as another reason for depicting contemporary Christian ethics as "ethics of responsibility" in as far as it recognises this responsibility.

A closer reading of Huber's discussion of the other structural elements also reveals two other fundamental and contemporary responsibilities that Christian ethics have to take on today. The first 
responsibility also has to do with the challenge that the increasing moral plurality puts to ethics. To counter the lack of cooperation that results from this moral plurality we have the responsibility to reconstruct opportunities for shared responsibility. In Huber's opinion it entails the responsibility to contribute constructively to the search for a planetary ethos that can provide minimal conditions for the survival of humankind and the preservation of nature. This fundamental and contemporary responsibility reminds one of the responsibility to seek consensus through dialogue on what we should make each other morally responsible for, emphasised by Fischer.

The second responsibility has to do with the increasing autonomy partial systems of society, such as the economy and politics, have claimed for themselves since the Enlightenment. As a result of this claim to autonomy, the tendency to recognise only functional values, and - for the most part - ignore moral values, has become prevalent in these social systems. This poses a challenge to Christian ethics and holds it responsible to participate in the ongoing struggle to see to it that criteria of humanity prevail in the ambiguous conditions of action in society. With the responsibility to salvage the status and applicability of morality in all spheres of life, Huber has identified yet another fundamental and distinctly contemporary way in which responsibility should mark Christian ethics in our day and which also may justify its depiction as "responsibility ethics".

Of the three theologians discussed Körtner most explicitly asserts that Christian ethics today should be conceived of and practiced as an ethics of responsibility, because the concept of responsibility, in his opinion, reflects a change in the fundamental understanding of morality. In an ethics of responsibility the concept of responsibility does not serve as substantive moral principle, but integrates substantive normative conceptions of value, duty and virtue in the fundamental moral situation that is characterised as forensic. In the fundamental moral situation the moral agent does not have to obey specific duties promulgated by a heteronomous or autonomous lawmaker as in the ethics of norms and the ethics of conviction respectively, but has to give account of her actions to an instance holding her accountable for her actions and their consequences. Christian ethics of responsibility asserts that the moral agent is accountable to God in the final instance. 
Someone like Fischer may, of course, play devil's advocate and counter that the idea of God as final Judge is as old as the religion of Ancient Israel and that the perception of the fundamental moral situation as forensic in nature is anything but new. Personally, I am of the opinion that it would indeed be difficult to deny that the fundamental moral situation was already in Ancient Israel, at least partly, perceived as a forensic one. For that reason I also wonder whether the depiction of the fundamental moral situation in exclusively forensic terms does justice to its distinctly contemporary nature. In the forensic depiction the association of retrospective responsibility for past actions is still predominant. As Körtner himself, however, emphasises: the fundamental moral situation entails more than just giving account before God or another instance of what one has done in the past. The fundamental moral situation consists also of the constitution of the relevant moral directive(s), the personal assumption of the moral directive(s) as one's own obligation and the application of this (these) moral directive(s) in real-life situations. In Ancient Israel the moral directive was constituted by the command of God as Lord and King and its assumption and application meant absolute and strict obedience to his command. As a result of the fact that we now live in a completely different situation one has to take into account that the assumption and application of the relevant moral directive(s) entails at least trying to do justice not only to these moral directives, but also to the functional directives that play a role in the different social systems. The responsibility to avoid risks to the environment and future generations adds the obligation to take also the consequences of different options for action into account. As a result of the moral plurality prevalent in most contemporary societies, and often also in religious denominations, we often have the responsibility first of all to constitute a moral consensus. Sometimes we even have the responsibility to formulate new moral directives that are applicable to completely new moral issues. This means that even for Christians the fundamental moral situation today does not consist so much in 1 . receiving God's command; 2. obeying God's command; and 3. giving account to God of their obedience or lack of obedience. It rather consists in taking on the comprehensive task of: 1 . constituting moral obligation by finding consensus on the relevant moral directives, formulating new moral directives where relevant ones are lacking, balancing moral and functional directives and weighing up the consequences of options for action; 2. making 
ethical decisions and acting in accordance with them in real-life situations; and 3. giving account to oneself, to other people and to God of this comprehensive responsibility.

To me it is clear that the distinctly contemporary nature of the fundamental ethical situation is not adequately described by making use of only forensic metaphors. I am of the opinion that apart from the forensic associations of the contemporary concept of responsibility, its associations to also the concept of calling or vocation should be explored. If the close association of responsibility with calling - which I believe it already had in Max Weber's original conception of an ethics of responsibility - is taken into account, it would become even more clear why the fundamental ethical situation is best depicted by the term "responsibility". The reason is that it would then be acknowledged that "responsibility" do not only refer to the account we have to give of, but also the assumption of the comprehensive task we have to realise morality in complex real-life situations.

\section{CONCLUSION ON THE PROSPECTS OF A CHRISTIAN ETHICS OF RESPONSIBILITY}

On the basis of the analysis and evaluation of Fischer's, Huber's and Körtner's conceptions I conclude that the prospects of a Christian ethics of responsibility are not as bleak as a superficial comparison of the disparate versions of such an ethics would suggest. If Christian ethics steers away from following Hans Jonas' example too closely in elevating responsibility to a substantive principle and reducing itself to a future ethics, and rather takes its cue from the ways - indicated in this article - in which responsibility should stamp contemporary ethics in a fundamental way, I am of the opinion that the prospects of a Christian ethics of responsibility are indeed quite promising.

In the critical discussion of the theologians' views at least five ways in which responsibility should fundamentally qualify contemporary Christian ethics have been identified:

- Christians should not regard their moral obligations as narrow and very specific moral commands or duties that they have to fulfill in obedience to God, but rather as broad and comprehensive moral responsibilities that they have to assume and to give account of to themselves, fellow human beings and God. 
- They have the responsibility to contribute to the constitution of moral obligations in our time, which entails the responsibility to formulate new moral directives where necessary, find the moral consensus needed in particular situations of moral decision making, as well as the responsibility to conclude agreements or covenants among those involved to commit themselves to act in accordance with the moral consensus, where such a commitment is lacking.

- They have the responsibility to do justice to both moral obligations and the functional obligations that are prevalent in the different social systems without forfeiting the priority of moral obligations.

- They also have the responsibility in the present situation, earmarked by moral plurality, to take into account the consequences of the available options for action, especially their effect on the freedom of conscience of people who do not share their moral convictions.

- The responsibility to take the consequences of available options for action into account also relates to the consequences such actions would have for the preservation of the environment and for the survival and quality of life of future generations.

These fundamental ways in which responsibility can and should qualify contemporary Christian ethics have been identified in a comparison and analysis of the views of a select number of theologians who are proponents of a Christian ethics of responsibility. What is still lacking is a more systematic exposition of the fundamental role that responsibility can and should play in contemporary ethics. In such a systematic exposition other important contributions to the discussion on the ethics of responsibility will have to be taken into account. Special attention should, in my opinion, be given to Max Weber's original distinction between an ethics of conviction and an ethics of responsibility in his famous lecture "Politik als Beruf". He was the first to realise the need for such an ethics and to identify some of its defining features ${ }^{7}$. He conceptualised the ethics of responsibility not as a new normative ethics, but rather meta-ethically as an approach to contemporary

$7 \quad$ See the list of consulted literature for details. 
problems that any ethics should take if wants to be adequate. Had the contemporary discussions on a Christian ethics of responsibility critically related more to his original conception than to Jonas's, I believe, the confusion that characterises this discussion would probably have been less.

Such a systematic exposition will also have to address a pivotal question. The depiction "Christian ethics of responsibility" implies: comprehensive human responsibility does and should take a central position in contemporary Christian ethics. But is it appropriate to allocate to comprehensive human responsibility such a central position in Christian ethics? The answer to this question does not only depend on whether it can be argued convincingly that such a central position is not in conflict with central Christian convictions regarding God's reign and providence and the believer's dependence on the guidance of the Holy Spirit. It will also depend on whether a convincing demonstration can be provided that central beliefs of the Christian faith positively point to the comprehensive fulfilment of human responsibility in our time.

\section{Consulted literature}

Bonhoeffer, D 1998. Ethik. Gütersloh:Chr Kaiser/Gütersloher Verlagshaus.

-, 1964. Widerstand und Ergebung: Briefe und Aufzeichnungen aus der Haft. München: Chr Kaiser Verlag.

De Villiers, D E 2006. Prospects of a Christian ethics of responsibility (Part 1): An assessment of an American version, Verbum et Ecclesia 27(2), 468-487.

Fischer, J 1992. Christliche Ethik als Verantwortungsethik?, Evangelische Theologie 52 (2), 114-128.

-, 1994. Leben aus dem Geist: Zur Grundlegung christlicher Ethik. Zürich: Theologischer Verlag.

-, 1998. Handlungsfelder angewandter Ethik: Eine theologische Orientierung. Stuttgart, Berlin, Köln: Verlag W Kohlhammer.

-, 2002. Theologische Ethik: Grundwissen und Orientierung. Stuttgart, Berlin, Köln: Verlag W Kohlhammer.

Huber, W 1990. Konflikt und Konsens: Studien zur Ethik der Verantwortung. München: Chr Kaiser Verlag.

-, 1992a. Selbstgegrenzung aus Freiheit: Über das ethische Grundproblem des technischen Zeitalters, Evangelische Theologie 52, 128-146.

-, 1992b. Strukturen verantwortlichen Lebens: Die Bedeutung Heinz Eduard Tödts für die theologische Ethik (Vortrag bei der Akademischen Gedenkfeier in Heidelberg am 6. Mai 1992). 
-, 1993. Toward an ethics of responsibility, The Journal of Religion 73(4), 573-592.

-, 1994. Gewalt gegen Mensch und Natur - Die Notwendigkeit eines planetarischen Ethos, in: J Rehm (ed.), Verantwortlich Leben in der Weltgemeinschaft: Zur Auseinandersetzung um das "Projekt Weltethos". Gütersloh: Chr Kaiser/Gütersloher Verlagshaus.

Jonas, H 1984. Das Prinzip Verantwortung: Versuch einer Ethik für die technologische Zivilisation. Frankfurt am Main: Suhrkamp.

-, 1984. The imperative of responsibility: In search of an ethics for the technological age. Chicago \& London: The University of Chicago Press.

Jonsen, A R 1968. Responsibility in modern religious ethics. Washington, Cleveland: Corpus Books.

Körtner, U H J 1996. Dem Risiko trotzen: Grundzüge einer zeitgemässen Verantwortungsethik, Evangelische Kommentare 29(10), 581-586.

-, 1997a. Prinzip Verantwortung? Begründungsprobleme heutiger Verantwortungsethik, Glaube und Lernen 12(2), 136-147.

-, 1997b. Solange die Erde steht: Schöpfungsglaube in der Risikogesellschaft. Hannover: Lutherisches Verlagshaus.

-, 1999. Evangelische Sozialethik: Grundlagen und Themenfelder. Göttingen: Vandenhoeck \& Ruprecht.

-, 2001. Freiheit und Verantwortung: Studien zur Grundlegung theologischer Ethik. Freiburg/Ue: Universitätsverlag; Freiburg/Br: Verlag Herder.

Kress, H \& Müller, W E 1997. Verantwortungsethik heute: Grundlagen und Konkretionen einer Ethik der Person. Stuttgart, Berlin, Köln: Verlag W Kohlhammer.

McKeon, R 1957. The development and the significance of the concept of responsibility, Revue internationale de philosophie 39, 3-32.

Mitcham, C 1987. Responsibility and technology. The expanding relationship, in: PT Durbin (ed). Technology and responsibility. Dordrecht: D Reidl Publishing Company, 3-39.

Niebuhr, H R 1978. The responsible self: An essay in Christian moral philosophy. San Francisco: Harper.

Römelt, J 1991. Theologie der Verantwortung: Zur theologischen Auseinandersetzung mit einem philosophischen Prinzip. Innsbruck: Resch Verlag.

-, 1996. Vom Sinn moralischer Verantwortung: Zu den Grundlagen christlicher Ethik in komplexer Gesellschaft. Regensburg: Verlag Friedrich Pustet.

Schweiker, W 1995. Responsibility and Christian ethics. Cambridge: University Press.

Weber, M 1994. Wissenschaft als Beruf 1917/1919. Politik als Beruf 1919: Studienausgabe. Tübingen: Mohr Siebeck. 